\title{
Abnormal Renin Short Feedback Loop in Essential Hypertension Is Reversible with Converting Enzyme Inhibition
}

\author{
Meryl S. LeBoff, Robert G. Dluhy, Norman K. Hollenderg, \\ Thomas J. Moore, Richard J. Koletsky, and Gordon H. Williams, \\ Departments of Medicine and Radiology, Brigham and Women's Hospital, \\ Boston, Massachusetts 02115
}

A B S T R A C T The suppression of renin release by angiotensin II (AII) (the so-called short feedback loop) is blunted in essential hypertension. To determine whether this abnormality is reversible, renin release was assessed in sodium-restricted essential hypertensives and normal controls: (a) during the administration of captopril for varying intervals and $(b)$ following the infusion of graded doses of AII $(0.3-3 \mathrm{ng} / \mathrm{kg}$ per min) before and after plasma levels of AII had been chronically reduced with captopril (25-50 $\mathrm{mg}$ every $6 \mathrm{~h})$ for $70 \mathrm{~h}$.

In control subjects, the maximal increment above control in plasma renin activity (PRA) after a single dose of captopril $(11.9 \pm 3 \mathrm{ng} / \mathrm{ml}$ per $\mathrm{h})$ was significantly $(P<0.02)$ greater than in hypertensives $(8.1 \pm 1.7$ $\mathrm{ng} / \mathrm{ml}$ per $\mathrm{h}$ ) despite similar reductions in AII levels and significantly greater decrements in diastolic blood pressure in the hypertensives. When captopril was continued for $70 \mathrm{~h}$, the PRA increments above base line in hypertensive subjects $(11.4 \pm 2.9 \mathrm{ng} / \mathrm{ml}$ per $\mathrm{h})$ rose to levels seen in the controls $(11 \pm 2.6 \mathrm{ng} / \mathrm{ml}$ per $\mathrm{h})$; there were no significant differences in the AII or diastolic blood pressure decrements between the two groups.

Compared with normotensive subjects, AII failed to suppress renin release in hypertensive subjects despite significantly greater diastolic blood increments and comparable AII levels achieved at each AII dose.

After captopril treatment, AII now produced significant declines in PRA in the hypertensives; moreover, comparing declines pre- and postcaptopril,

This work was presented at the 63rd Annual Meeting of the Endocrine Society, Abstract 714, Cincinnati, OH.

Address reprint requests to Dr. Dluhy.

Received for publication 4 January 1982 and in revised form 19 March 1982. greater PRA decrements were seen either at comparable rises in levels of AII or diastolic blood pressure. Finally, the suppression of PRA by AII postcaptopril in hypertensives was now indistinguishable from that seen in normal controls. Thus, the impaired regulation of renin by AII is reversible with prolonged captopril treatment, suggesting that this abnormality is not due to a fixed structural defect but to a reversible lesion.

\section{INTRODUCTION}

An increased intrarenal concentration of angiotensin II (AII) ${ }^{1}$ reduces renin release, the so-called "short feedback loop," and is thought to be one important determinant of renin release in normal man (1-7). We have demonstrated a blunted action of AII in limiting renin release in patients with essential hypertension (8). Whether this abnormality was due to a fixed, structural defect or was reversible was not determined. To further investigate this, we measured plasma renin activity (PRA) during the administration of captopril for varying intervals, and assessed the responsiveness of the short feedback loop to AII when plasma (and presumably intrarenal) AII concentrations had been reduced for intervals up to $70 \mathrm{~h}$.

\section{METHODS}

55 hypertensive subjects (10 females, 45 males) and 31 normotensive control subjects ( 5 females, 26 males) were studied on the Clinical Research Center of the Brigham and Women's Hospital. Hypertensive patients ranged in age from 18 to 69 yr of age; normal controls ranged from 20 to $54 \mathrm{yr}$. All hypertensive subjects had a diastolic blood pressure $>90 \mathrm{~mm}$

\footnotetext{
${ }^{1}$ Abbreviations used in this paper: AII, angiotensin II; DBP, diastolic blood pressure; FDPT, Fisher direct probability test; PRA, plasma renin activity.
} 
of mercury on three separate occasions before admission and a documented history of hypertension for at least 6 mo duration. Antihypertensive medications were discontinued 2 wk before admission. All hypertensive subjects had normal 24-h urine excretion values for vanillyl-mandelic acid, metanephrines, catecholamines, 17-hydroxysteroids, and 17-ketosteroids. Two hypertensive patients had renal artery stenosis. In the remainder rapid sequence intravenous pyelography and/or renograms were normal; renal arteriography with bilateral renal vein sampling for renin levels were performed when indicated.

All studies were performed in balance on a 10 -meq sodium, 100-meq potassium isocaloric diet. After sodium balance had been achieved, renin levels were obtained supine and after subjects had been upright for $2 \mathrm{~h}$. The range of upright renin levels in normal controls in our laboratory on a 10 -meq sodium diet is 2.5 to $15 \mathrm{ng} / \mathrm{ml}$ per $\mathrm{h}(9)$. Four hypertensive patients (two with essential hypertension and two with renal artery stenosis) had upright PRA levels exceeding $15 \mathrm{ng} / \mathrm{ml}$ per $\mathrm{h}$ (high renin hypertension). In the remaining hypertensives, upright PRA levels were within the normal range. All subsequent studies were performed recumbent following an overnight fast at 8:00 a.m. Arterial blood pressure was monitored at 2-min intervals with an automatic blood pressure recorder (Arteriosonde, Roche Diagnostics Div., Hoffman-La Roche Inc., Nutley, NJ) for a 30 -min control period and during each AII infusion, or after captopril administration.

\section{Protocols}

\section{CONVERTING ENZYME INHIBITION}

Single dose. 39 hypertensive subjects and 14 normal controls received a single 12.5-50-mg dose of captopril (SQ 14225, Squibb Pharmaceutical Co., Princeton, NJ) by mouth. Supine blood samples were obtained for sodium, potassium, PRA, and AII before the dose, at 30-min intervals for $2 \mathrm{~h}$, and at $6 \mathrm{~h}$.

Multiple dose. In 16 hypertensive subjects and 12 normotensive subjects, captopril (25-50 mg every $6 \mathrm{~h}$ ) was continued for $70 \mathrm{~h}$. Supine blood samples were drawn at 8:00 a.m. for PRA, AII, sodium, and potassium after $70 \mathrm{~h}$ of captopril therapy.

To insure comparability of renin levels in hypertensive and normal studies after single or multiple dose captopril treatment, all PRA samples were obtained 90-120 min after the morning captopril dose.

\section{Infusion of AII pre-and postcaptopril}

Precaptopril. To assess the short feedback suppression of PRA by AII, AII (Hypertensin; Ciba-Geigy Corp., Summit, $\mathrm{NJ})$ was infused in graded doses $(0.3,1$, and $3 \mathrm{ng} / \mathrm{kg}$ per min) in 16 hypertensive and in 13 normotensive subjects on a 10-meq sodium, 100-meq potassium diet. Each dose was given for $45 \mathrm{~min}$. At the end of each dose, blood samples were obtained for PRA, AII, sodium, and potassium.

Postcaptopril. AII was inf used in 16 hypertensive subjects following treatment with captopril (25-50 mg per os every $6 \mathrm{~h}$ ) for $70 \mathrm{~h}$. As previously, AII was infused at $0.3,1$, and $3 \mathrm{ng} / \mathrm{kg}$ per $\mathrm{min}$, with each dose given for $45 \mathrm{~min}$. Following each infusion dose, blood samples were obtained for PRA, AII, sodium, and potassium. Seven normotensive subjects also had AII infusions at $0.3,1,3$, and $10 \mathrm{ng} / \mathrm{kg}$ per min after $70 \mathrm{~h}$ of captopril ( $25 \mathrm{mg}$ per os every $6 \mathrm{~h}$ ).

Laboratory techniques. All blood samples were collected on ice and centrifuged immediately. AII was measured with a double-antibody radioimmunoassay, and PRA with a radioimmunoassay of the angiotensin I generated during a 30min incubation with endogenous substrate at $37^{\circ} \mathrm{C}(10,11)$. 24-h urines were collected for sodium, potassium, and creatinine. Urine sodium and potassium were measured by flame photometry using lithium as the internal standard.

Statistical evaluation. Means have been presented with the SEM as the index of dispersion. Statistical significance was determined with the $t$ test, or analysis of regression where applicable. In some instances, the Fisher direct probability test (FDPT) or Wilcoxon Rank Sum Test for nonparametric data were used (12). The null hypothesis was rejected when a $P$ value of $<0.05$ was obtained. The protocols were approved by the Human Subjects Committee of the Brigham and Women's Hospital; in all cases, informed consent was obtained.

\section{RESULTS}

\section{Response to converting enzyme inhibition}

Single dose. The physiologic responses to a single dose of captopril are summarized in Table I. The maximum increase in PRA was significantly greater in the normotensive than the hypertensive subjects $(11.9 \pm 3$ vs. $8.1 \pm 1.7 \mathrm{ng} / \mathrm{ml}$ per h, respectively, $P<0.02$, FDPT). This occurred despite significantly greater falls in diastolic blood pressure (DBP) in the hypertensive group $(P<0.02$, FDPT $)$. On the other hand, there were no significant differences in the decreases in AII levels between hypertensive and normal subjects (Table I).

Multiple dose over $70 \mathrm{~h}$. Captopril was continued for $70 \mathrm{~h}$ in 12 normal controls and 16 hypertensive subjects (Table I). In the hypertensive subjects, the mean decline in DBP was identical to that observed after a single dose $(-16 \pm 2 \mathrm{~mm} \mathrm{Hg})$. However, after $70 \mathrm{~h}$ of captopril, the mean PRA increment was $11.4 \pm 2.9 \mathrm{ng} / \mathrm{ml}$ per $\mathrm{h}$; this PRA rise was not statisti-

TABLE I

Responses to Converting Enzyme Inhibition with Captopril

\begin{tabular}{|c|c|c|c|c|}
\hline & \multicolumn{4}{|c|}{ Single dose } \\
\hline & \multicolumn{2}{|c|}{ Normals, $n=14$} & \multicolumn{2}{|c|}{ Hypertensives, $n=39$} \\
\hline & Control & $\Delta^{\bullet}$ & Control & $\Delta^{\bullet}$ \\
\hline PRA, $n g / m l / h$ & $3.9 \pm 0.6$ & $+11.9 \pm 3$ & $3.5 \pm 0.3$ & $+8.1 \pm 1.7 t$ \\
\hline AII, $p g / m l$ & $26 \pm 4$ & $-11 \pm 2$ & $20 \pm 2$ & $-7 \pm 2$ \\
\hline \multirow[t]{3}{*}{$\mathrm{DBP}, \mathrm{mm} \boldsymbol{H g}$} & $71 \pm 1$ & $-14 \pm 2$ & $88 \pm 2$ & $-16 \pm 11$ \\
\hline & \multicolumn{4}{|c|}{ Multiple dose } \\
\hline & \multicolumn{2}{|c|}{ Normals, $n=12$} & \multicolumn{2}{|c|}{ Hypertensives, $n=16$} \\
\hline PRA, $n g / m l / h$ & $3.1 \pm 0.4$ & $+11 \pm 2.6$ & $4.6 \pm 0.8$ & $+11.4 \pm 2.9$ \\
\hline AII, $p g / m l$ & $39 \pm 5$ & $-21 \pm 4$ & $35 \pm 5$ & $-8 \pm 4$ \\
\hline DBP, $m m \boldsymbol{H g}$ & $70 \pm 3$ & $-13 \pm 3$ & $89 \pm 2$ & $-16 \pm 2$ \\
\hline
\end{tabular}

$\bullet \Delta=$ Maximum change from control levels.

$\downarrow P<0.02$ different from normals, Fisher direct probability test. 
cally different from that observed in normotensive subjects treated with either a single dose $(11.9 \pm 3 \mathrm{ng} / \mathrm{ml}$ per h) or after $70 \mathrm{~h}$ of captopril $(11 \pm 2.6 \mathrm{ng} / \mathrm{ml}$ per $\mathrm{h})$. After either single or multiple dose captopril administration, there were no significant differences in the AII or DBP decrements in the hypertensive and normotensive subjects (Table I). However, in the normotensive subjects, the declines in AII were greater, although not significantly so, following both single and multiple dose captopril administration compared with the hypertensive subjects.

Response to AII infusion before captopril. The mean basal PRA levels in the hypertensive subjects $(4.6 \pm 0.8 \mathrm{ng} / \mathrm{ml}$ per $\mathrm{h})$ and in the normotensive controls $(4.5 \pm 0.7 \mathrm{ng} / \mathrm{ml}$ per $\mathrm{h})$ were not significantly different and were nearly identical. The basal AII concentrations as well as the AII levels achieved at each infusion dose also were not significantly different in normotensive and hypertensive subjects. PRA did not fall in either normotensive or hypertensive subjects at an AII infusion rate of $0.3 \mathrm{ng} / \mathrm{kg}$ per min, but did, in both groups with larger doses (Fig. 1). As anticipated, the mean decrements in PRA were significantly greater in normotensive than in hypertensive subjects at 1 and $3 \mathrm{ng} / \mathrm{kg}$ per $\min (P<0.027$, and $P<0.001$, respectively). Compared with the response seen in normotensive subjects, AII failed to suppress renin release in

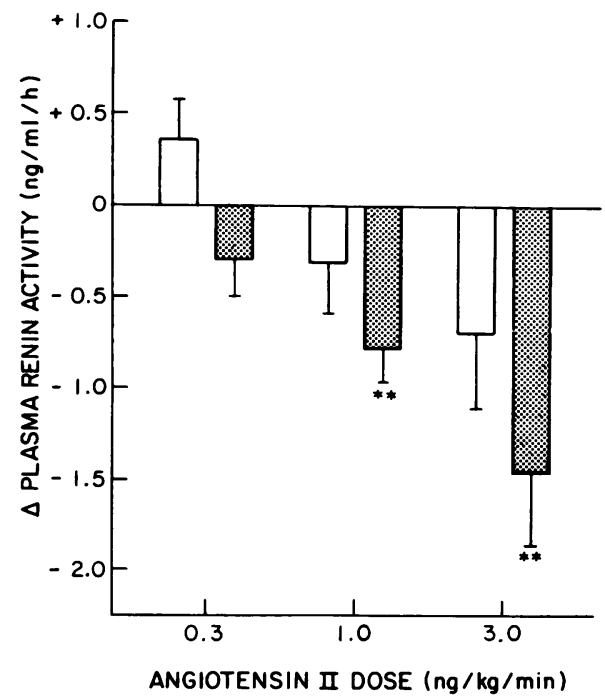

Figure 1 The mean maximal PRA decrements from control after the infusion of $\mathrm{AII}$ at $0.3,1$, and $3 \mathrm{ng} / \mathrm{kg}$ per min in normotensive and hypertensive subjects before captopril administration. Recumbent control PRA levels in hypertensives $=4.6 \pm 0.8 \mathrm{ng} / \mathrm{ml}$ per $\mathrm{h}$ and in normals $=4.5 \pm 0.71 \mathrm{ng} / \mathrm{ml}$ per $h .{ }^{\circ}$ Mean decrements in PRA are significantly greater in normotensive than in hypertensive subjects at 1 and $3 \mathrm{ng} /$ kg per $\min (P<0.027$ and $P<0.001$, respectively $)$. $\square$, Hypertensive precaptopril $(n=16) ; \square$, normotensive $(n=13)$. hypertensive subjects despite significantly greater increments in diastolic blood pressure at each AII dose.

\section{AII infusion after converting enzyme inhibition with captopril}

Hypertensive subjects. To study the question of the reversibility of the previously defined abnormalities in the short feedback suppression of PRA by AII, AII was infused in hypertensive subjects after $70 \mathrm{~h}$ of captopril. Compared with the PRA responses precaptopril, AII infusion now produced significant declines in the levels of PRA at $0.3 \mathrm{ng} / \mathrm{kg}$ per $\min (-3.3 \pm 1.2$ $\mathrm{ng} / \mathrm{ml}$ per h, $P<0.01), 1 \mathrm{ng} / \mathrm{kg}$ per $\min (-6.2 \pm 2.0$ $\mathrm{ng} / \mathrm{ml}$ per h, $P<0.02)$ and $3 \mathrm{ng} / \mathrm{kg}$ per $\min (-8.1 \pm 2.4$ $\mathrm{ng} / \mathrm{ml}$ per $\mathrm{h}, P<0.01$ ) (Fig. 2, Table II). This suppression of PRA in response to AII after captopril was associated with AII increments that were not significantly different from those recorded in the precaptopril AII infusions (Table II). Comparing pre- and postcaptopril DBP rises, there was increased vascular responsiveness at each AII infusion dose in hypertensive subjects following captopril $(P<0.05)$. However, when identical DBP increments $(5 \mathrm{~mm} \mathrm{Hg})$ following AII pre- and postcaptopril were compared, there were greater declines in PRA following captopril both at

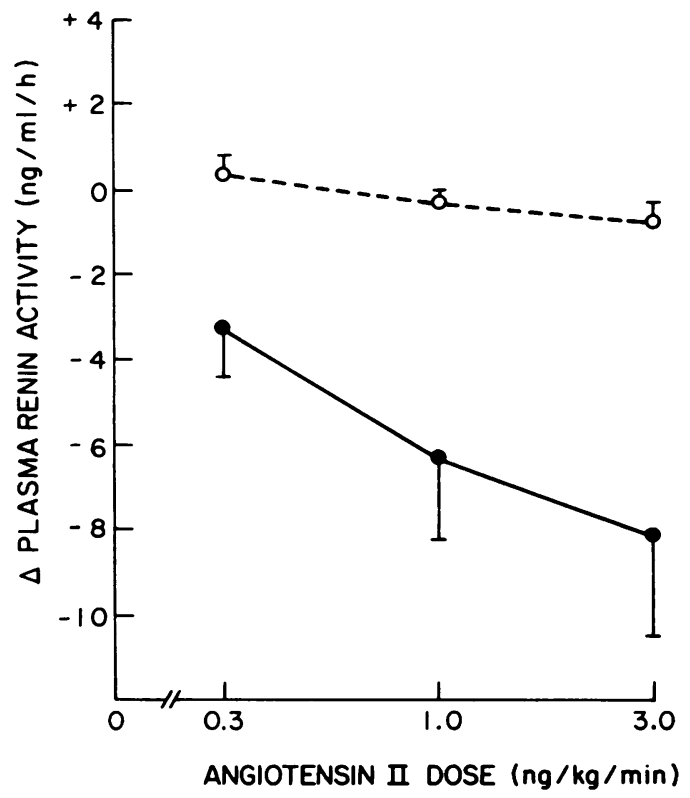

Figure 2 The mean maximal PRA decrements from control after the infusion of AII at $0.3,1$, and $3 \mathrm{ng} / \mathrm{kg}$ per $\mathrm{min}$ in hypertensive subjects pre- and postcaptopril administration (25-50 mg p.o. every $6 \mathrm{~h}$ for $70 \mathrm{~h}$ ). Absolute PRA levels are presented in Table II. $O---O$, Precaptopril, $n=16$; -1 , post captopril, $n=13$. 
TABLE II

AII Infusions in 16 Hypertensive Subjects Preand Postcaptopril Administration

\begin{tabular}{lccc}
\hline AIl infusion rate & PRA & AII & DBP \\
\hline $\begin{array}{c}n g / \mathrm{kg} / \mathrm{min} \\
\text { Precaptopril }\end{array}$ & $n g / \mathrm{ml} / \mathrm{h}$ & $p g / m l$ & $\mathrm{~mm} / \mathrm{Hg}$ \\
Control & & & \\
0.3 & $4.6 \pm 0.8$ & $35 \pm 5$ & $89 \pm 2$ \\
1.0 & $4.9 \pm 1.0$ & $37 \pm 5$ & $91 \pm 2$ \\
3.0 & $4.2 \pm 0.9$ & $43 \pm 7$ & $94 \pm 2$ \\
& $3.9 \pm 0.7$ & $62 \pm 10$ & $99 \pm 2$ \\
Postcaptopril & & & \\
Control & $16.5 \pm 3.7$ & $27 \pm 3$ & $74 \pm 2$ \\
0.3 & $13.2 \pm 3.1$ & $29 \pm 2$ & $79 \pm 2$ \\
1.0 & $10.2 \pm 1.9$ & $36 \pm 3$ & $85 \pm 2$ \\
3.0 & $8.4 \pm 1.6$ & $53 \pm 8$ & $92 \pm 2$ \\
\hline
\end{tabular}

lower AII infusion rates $(P<0.05)$ and lower AII levels $(P<0.025)$ (Table II).

Two patients with renal artery stenosis displayed a marked change in the suppression of PRA in response to AII pre- and postcaptopril. Before captopril therapy, AII infused at $3 \mathrm{ng} / \mathrm{kg}$ per min produced a PRA decline of -3.4 and $-1.0 \mathrm{ng} / \mathrm{ml}$ per $\mathrm{h}$. After captopril, AII infused at $3 \mathrm{ng} / \mathrm{kg}$ per min produced PRA decrements of -34 and $-13.6 \mathrm{ng} / \mathrm{ml}$ per $\mathrm{h}$, respectively.

Hypertensive vs. normal subjects. Regression analysis of the relationship between the decrease in PRA in response to AII precaptopril revealed that in normal subjects, the decline in PRA was a function of the con- trol PRA ( $r=0.79, P<0.001$ ) (Fig. 3). Moreover, in normal subjects treated with captopril, this regression relationship was not altered $(r=0.93, P<0.001)$.

In hypertensive subjects precaptopril, regression analysis revealed no significant relationship between control PRA and the decline in PRA in response to infused AII ( $3 \mathrm{ng} / \mathrm{kg}$ per $\mathrm{min})(r=0.40)$ (Fig. 3). However, when AII was infused in hypertensive subjects postcaptopril, control PRA now strongly correlated with the decline in PRA $(r=0.96, P<0.001)$ (Fig. $3)$. Although there were no significant differences in the AII levels at each dose, the DBP response at each AII dose was significantly less in the normotensive than the hypertensive subjects.

To compare the suppression of PRA at equivalent DBP increases, AII was also infused at $10 \mathrm{ng} / \mathrm{kg}$ per min in seven normal subjects after treatment with captopril for $70 \mathrm{~h}(25 \mathrm{mg}$ every $6 \mathrm{~h})$. At $10 \mathrm{ng} / \mathrm{kg}$ per min in the normal subjects, the DBP rise $(+19 \pm 2 \mathrm{~mm} \mathrm{Hg})$ was not significantly different from that seen in the hypertensive subjects $(+18 \pm 2 \mathrm{~mm} \mathrm{Hg})$ following an AII infusion dose of $3 \mathrm{ng} / \mathrm{kg}$ per min. As expected, the mean AII levels achieved in normotensive subjects at $10 \mathrm{ng} / \mathrm{kg}$ per $\min (+70 \pm 16 \mathrm{pg} / \mathrm{ml})$ were significantly greater than those in hypertensives at $3 \mathrm{ng} / \mathrm{kg}$ per min $(+20 \pm 8 \mathrm{pg} / \mathrm{ml})$. In the setting of nearly identical DBP rises, the mean postcaptopril PRA decline in the normotensive subjects in response to AII at $10 \mathrm{ng} / \mathrm{kg}$ per $\min (-6 \pm 1.5 \mathrm{ng} / \mathrm{ml}$ per h) now was not significantly different from the mean decrease in PRA $(-8 \pm 2.4 \mathrm{ng} /$

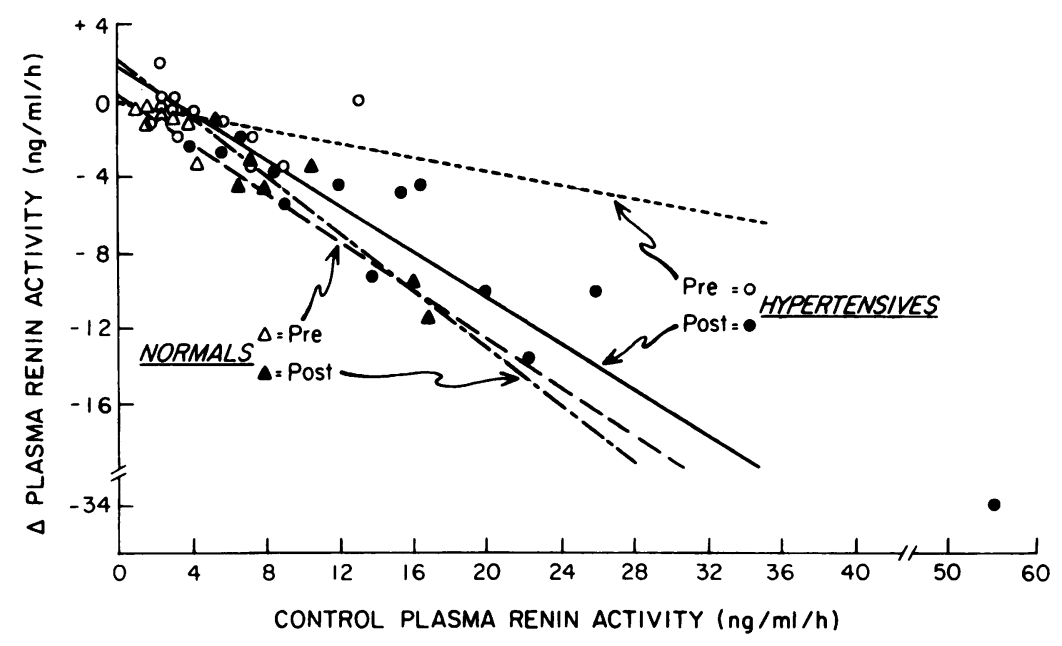

Figure 3 Regression relationships between control PRA and the decrement in PRA after the infusion of angiotensin II in normotensive $(n=7)$ and hypertensive subjects $(n=13)$ pre- and postcaptopril. In hypertensive subjects before captopril, there was no significant regression relationship between the PRA decrement in response to AII and control PRA $(r=0.40, P$ $>0.05)$. After $70 \mathrm{~h}$ of captopril, there was a significant regression relationship $(r=0.96, P$ $<0.001)$ in hypertensives which was similar to that observed in normotensive subjects both pre $(r=0.79, P<0.001)$ and post $70 \mathrm{~h}$ of captopril $(r=0.93, P<0.001)$. 
$\mathrm{ml}$ per $\mathrm{h}$ ) in the hypertensive subjects at a dose of 3 ng/kg per min (Fig. 4).

\section{DISCUSSION}

Circulating AII levels directly regulate renin release independent of any hemodynamic, neurogenic, or renal tubular mechanisms via the so-called short feedback loop $(1,13)$. In a previous study, we demonstrated that AII reduces renin release in normal sodium-restricted subjects at subpressor concentrations within the physiologic range (8). Further support for short feedback inhibition of PRA by AII in man is provided by the study of Kono et al. (14) where the infusion of the AII analogue, des-Asp ${ }^{1}$,-Ileu ${ }^{8}$-angiotensin II, suppressed captopril-induced PRA increases in normal man and hypertensive subjects without changes in arterial blood pressure. A direct effect of AII on reducing renin release has also been demonstrated in vitro (15).

Our study confirms an abnormal regulation of PRA by AII (short feedback loop) in essential hypertension (8) and extends that observation to indicate a subnormal response of PRA following converting enzyme inhibition with captopril. The reduced response to captopril indicates strongly a subnormal PRA response of the short feedback loop to AII not only when the concentration of AII rises, but also when it falls. The failure of AII to suppress PRA could not be explained by the AII levels or by the blood pressure responses achieved during the infusion of AII in normotensive

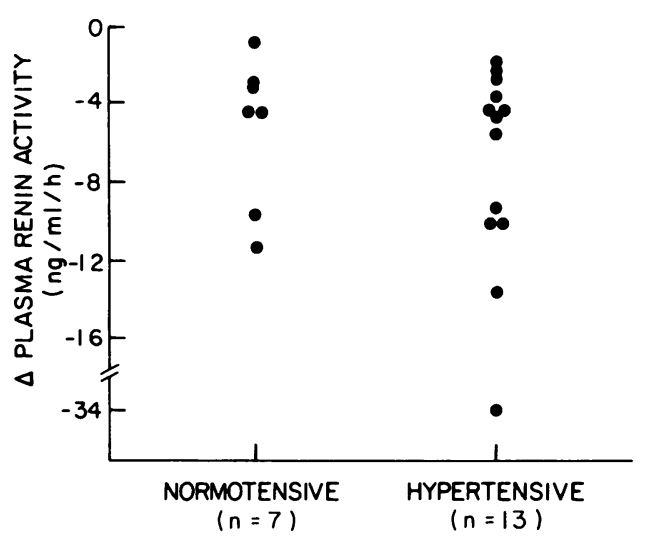

Figure 4 The maximal PRA decrements from control after the infusion of AII of $10 \mathrm{ng} / \mathrm{kg}$ per min (normotensive subjects) and $3 \mathrm{ng} / \mathrm{kg}$ per min (hypertensive subjects) after treatment with captopril for $70 \mathrm{~h}$ ( $25 \mathrm{mg}$ p.o. every $6 \mathrm{~h}$ ). Recumbent control PRA levels in hypertensives $=16.5 \pm 3.7$ $\mathrm{ng} / \mathrm{ml}$ per $\mathrm{h}$ and in normals $=10.1 \pm 1.8 \mathrm{ng} / \mathrm{ml}$ per $\mathrm{h}$. The mean DBP rises in hypertensives $(+18 \pm 2 \mathrm{~mm} \mathrm{Hg})$ and normotensive subjects $(+19 \pm 2 \mathrm{~mm} \mathrm{Hg})$ were not significantly different. The mean decline in PRA in normotensive $(-6 \pm 1.5$ $\mathrm{ng} / \mathrm{ml}$ per $\mathrm{h})$ and hypertensive subjects $(-8 \pm 2.4 \mathrm{ng} / \mathrm{ml}$ per h) were also not significantly different. and hypertensive subjects. Moreover, the failure to suppress PRA was seen in the presence of a greater rise in DBP in the hypertensive subjects at each AII infusion dose. The subnormal increment in PRA in hypertensive subjects following captopril occurred despite a significantly greater fall in DBP in the hypertensives and no significant differences in the fall of AII between hypertensive and normotensive subjects. Therefore, elevations or reductions in AII levels within the physiologic range revealed a decreased effectiveness of AII to modulate renin release in hypertensive subjects. This is probably not due to an elevated blood pressure per se, because many subjects had normal blood pressures at the time of study.

We reasoned that this abnormal AII-PRA interaction could be the result of structural abnormalities in the kidney secondary to chronically elevated blood pressure, such as renovascular atherosclerosis, arteriolar nephrosclerosis, or organic lesions of the juxtaglomerular apparatus. Alternatively, the abnormality could be caused by a derangement in renin release (such as a sustained elevation of intrarenal AII levels), which could be reversible. Therefore, captopril administration was continued for $70 \mathrm{~h}$ in hypertensive and normotensive subjects; in hypertensive subjects, the PRA increment now became indistinguishable from that seen in normotensive subjects. The return to normal of the PRA increase in hypertensive subjects could not be explained by a progressively greater hypotensive response or a greater AII decrement at $70 \mathrm{~h}$ because the DBP fall and the AII decrement were not significantly different than those observed after a single dose (Table I). There were also no significant differences between the AII decrements in the hypertensive vs. normotensive subjects after $70 \mathrm{~h}$ of captopril treatment. Changes in sodium balance cannot explain the differences in renin responsiveness after $70 \mathrm{~h}$ of captopril treatment, because patients were maintained on a severely sodium-restricted intake and their weights did not change. Thus, restoration of normal renin responsiveness following captopril suggested a reversible abnormality in the short feedback suppression of renin release by AII.

The PRA response to AII infusion postcaptopril treatment in hypertensive subjects supports this hypothesis. Compared with the PRA response precaptopril, the infusion of AII postcaptopril now produced significant decrements in PRA at $0.3,1$, and $3 \mathrm{ng} / \mathrm{kg}$ per min. This suppression of PRA could not be explained by differences in AII levels achieved because they were not significantly different pre- and postcaptopril. As expected, the absolute mean DBP at each AII infusion dose was less after than before captopril administration. However, greater blood pressure rises were observed after the infusion of AII postcaptopril 
compared with precaptopril administration; this enhanced sensitivity in the sodium-restricted state has been previously reported and may reflect an increase of AII vascular receptors subsequent to lowering endogenous AII levels $(16,17)$. To exclude a possible role for greater blood pressure rises in explaining the results, we analyzed the decreases in PRA in hypertensives pre- and postcaptopril at comparable blood pressure increases. At nearly identical blood pressure rises, suppression of PRA was still significantly greater postcaptopril at lower AII infusion rates and at lower AII levels (Table II).

However, not only did captopril reverse the abnormality in the short feedback loop in hypertensive subjects but suppression of PRA by AII was now indistinguishable from that seen in normotensive subjects. This normalization of renin responsiveness to AII after captopril is clearly demonstrated by the regression relationship between control PRA and the decrement in PRA to infused AII (Fig. 3). In normotensive subjects, the decrement in PRA to infused AII was a function of control PRA; in hypertensive subjects precaptopril it was not. However, when AII was infused in hypertensive subjects treated with captopril, control PRA now strongly correlated with the decrement in PRA $(P<0.001)$ (Fig. 3). Additional evidence for normalization of PRA suppression by infused AII following captopril was seen when PRA decrements were compared in hypertensive and normal subjects at comparable blood pressure increments. In normotensive subjects at an AII infusion rate of $10 \mathrm{ng} / \mathrm{kg}$ per min, the DBP increment was nearly identical to that seen in hypertensive subjects at an AII dose of $3 \mathrm{ng} / \mathrm{kg}$ per min. At equivalent pressor responses, the mean decrement in PRA in normotensive subjects was now not significantly different from that seen in hypertensive subjects (Fig. 4). The fact that the $10 \mathrm{ng} / \mathrm{kg}$ per min AII infusion rate in the normotensive subjects did not produce a greater suppression of PRA due to the higher AII levels achieved is probably due to the flat dose response relationship between 3 and $10 \mathrm{ng} / \mathrm{kg}$ per $\mathrm{min}$, as previously reported (8). Thus, prolonged lowering of endogenous AII levels with captopril not only reversed the abnormalities in the short feedback loop in hypertensive subjects, but PRA responsiveness to AII appeared now to be indistinguishable from that seen in normotensive subjects.

There are a number of mechanisms whereby prolonged captopril treatment could restore renin responsiveness in hypertensive patients. For example, captopril produces rises in prostaglandin and bradykinin levels concomitant with the decrements in endogenous AII $(18,19)$. This increased prostaglandin production could provide an additional stimulus for renin release. An alternative hypothesis is that cap- topril lowers elevated intrarenal AII levels. AII is known to be generated in the kidney and arteriovenous AII gradients have been demonstrated across it (20). Higher than normal intrarenal AII levels could make the juxtaglomerular AII receptor less responsive to infused AII (similar to reports of the glomerular AII receptor) (21) or these levels could exert a renal arteriolar vasoconstrictive effect, thereby providing a stimulus for continuous renin release. Further indirect support for the postulated high intrarenal AII levels are the abnormalities noted in renal blood flow, which were promptly reversible with the converting enzyme inhibitor SQ 20881 (22).

Thus, hypertensive patients have a defect in the short feedback loop as evidenced by: (a) failure to exhibit the expected increment in PRA in response to the acute lowering of AII levels with captopril and (b) failure to suppress PRA in response to the infusion of AII. Prolonged treatment with captopril reverses these abnormalities in hypertensive subjects, perhaps by reducing sustained elevations in peripheral or intrarenal AII or blood pressure levels. Hence, the impaired regulation of renin by AII in hypertension is not due to a fixed structural lesion but to a reversible defect.

\section{ACKNOWLEDGMENTS}

We would like to acknowledge the secretarial assistance of Mrs. Nancy Orgill and Ms. Diane Rioux. The captopril was supplied by Drs. J. Knill and J. Stritar of the Squibb Pharmaceutical Co., Princeton, NJ.

This work was supported by grants from the National Institutes of Health (HL 14944, GM 16821, HL 18882, HL 05832 , AM 01629, and HL 05144). The studies were performed on a Clinical Research Center supported by a grant from the Division of Research Resources of the National Institutes of Health (RR00888).

\section{REFERENCES}

1. Davis, J. O. 1973. The control of renin release. Am. J. Med. 55: 333-350.

2. Vander, A. J., and G. W. Geelhoed. 1965. Inhibition of renin secretion by angiotensin II. Proc. Soc. Exp. Biol. Med. 120: 399-403.

3. De Champlain, J., J. Genest, R. Veyratt, and R. Boucher. 1966. Factors controlling renin in man. Arch. Intern. Med. 117: 355-363.

4. Bunag, R. D., I. H. Page, and J. W. McCubbin. 1967. Inhibition of renin release by vasopressin and angiotensin. Cardiovasc. Res. 1: 67-73.

5. Shade, R. E., J. O. David, J. A. Johnson, R. W. Gotshall, and W. S. Spielman. 1973. Mechanism of action of angiotensin II and antidiuretic hormone on renin secretion. Am. J. Physiol. 224: 926-943.

6. Michelakis, A. M., and R. Horton. 1970. The relationship between plasma renin and aldosterone in normal man. Circ. Res. 16/17: 185-194.

7. Mendelsohn, F. A. O., C. I. Johnston, A. E. Doyle, B. A. Scoggins, D. A. Denton, and J. P. Coghlan. 1972. Renin 
angiotensin II and adrenal corticosteroid relationships during sodium deprivation and angiotensin infusion in normotensive and hypertensive man. Circ. Res. 31: 728739.

8. Williams, G. H., N. K. Hollenberg, T. J. Moore, R. G Dluhy, S. Z. Bavli, H. S. Solomon, and J. H. Mersey. 1978. Failure of renin suppression by angiotensin II in hypertension. Circ. Res. 42: 46-52.

9. Tuck, M. L., G. H. Williams, J. P. Cain, J. M. Sullivan, and R. G. Dluhy. 1973. Relation of age, diastolic pressure and known duration of hypertension to presence of low renin essential hypertension. Am. J. Cardiol. 32: 637642 .

10. Underwood, R. H., and G. H. Williams. 1972. The simultaneous measurements of aldosterone, cortisol and corticosterone in human peripheral plasma by displacement analysis. J. Lab. Clin. Med. 79: 848-862.

11. Emanuel, R. L., J. P. Cain, and G. H. Williams. 1973. Double antibody radioimmunoassay of renin activity and angiotensin II in human peripheral plasma. J. Lab. Clin. Med. 81: 632-640.

12. Armitage, P. 1971. Statistical Methods in Medical Research. John Wiley \& Sons, Inc., New York.

13. Blair-West, J. R., J. P. Coghlan, D. A. Denton, J. W. Tunder, B. A. Scoggins, and R. D. Wright. 1971. Inhibition of renin secretion by systemic and intrarenal angiotensin infusion. Am. J. Physiol. 220: 1309-1315.

14. Kono, T., I. Fumitake, O. Fumimass, I. Hiroo, and E. Jivo. 1981. Suppression of captopril-induced increase in plasma renin activity by des-Asp ${ }^{1}-$, Ileu $^{8}$-angiotensin II in man. J. Clin. Endocrinol. Metab. 52: 354-358.

15. Michelakis, A. M. 1971. The effect of angiotensin II on renin production and release in vitro. Proc. Soc. Exp. Biol. Med. 138: 1106-1108.

16. Dawson-Hughes, B. F., T. J. Moore, R. G. Dluhy, N. K. Hollenberg, and G. H. Williams. 1981. Plasma angiotensin II concentration regulates vascular but not adrenal responsiveness to restriction of sodium intake in normal man. Clin. Sci. (Lond.). 61: 527-534.

17. Gunther, S., M. A. Gimbrone, and A. Wagner. 1980. Regulation by angiotensin II of its receptors in resistance blood vessels. Nature (Lond.). 287: 230-232.

18. Moore, T. J., F. R. Crantz, N. K. Hollenberg, R. J. Koletsky, M. S. LeBoff, S. L. Swartz, L. Levine, S. Podolsky, R. G. Dluhy, and G. H. Williams. 1981. Contribution of prostaglandins to the antihypertensive action of captopril in essential hypertension. Hypertension (Dallas). 3: 168-173.

19. Swartz, S. L., G. H. Williams, N. K. Hollenberg, L. Levine, R. G. Dluhy, and T. J. Moore. 1980. Captopril-induced changes in prostaglandin production. Relationship to vascular responses in normal man. J. Clin. Invest. 65: 1257-1264.

20. Hollenberg, N. K., G. H. Williams, K. J. Toub, I. Ishikawa, C. Brown, D. F. Adams. 1977. Renal vascular response to interruption of the renin-angiotensin system in normal man. Kidney Int. 12: 285-293.

21. Beaufils, M., J. Sraer, C. Lepreux, and R. Ardaillou. 1976. Angiotensin II binding to renal glomeruli from sodium-loaded and sodium-depleted rats. Am. J. Physiol. 230: 1187 .

22. Williams, G. H., and N. K. Hollenberg. 1977. Accentuated vascular and endocrine response to SQ 20881 in hypertension. N. Engl. J. Med. 297: 184-188. 